\title{
THE LEVEL OF CYTOKERATIN 18 IN PATIENTS WITH HIV AND VIRAL HEPATITIS C CO-INFECTION IN LATVIA
}

\author{
Oksana Koḷesova ${ }_{1}^{1,2, \#}$, Monta Madelāne ${ }_{1}^{1}$, Ilze Ekšteina ${ }^{1}$, Aleksandrs Koḷesovs ${ }^{1,3}$, \\ Angelika Krūmiṇa ${ }^{1}$, and Ludmila Vīksna ${ }^{1}$ \\ ${ }^{1}$ Faculty of Medicine, Rīga Stradiṇš University, 3 Linezera Str., Rĩga, LV-1006, LATVIA \\ 2 Institute of Microbiology and Virology, Rīga Stradiṇš University, 5 Rātsupītes Str., Rīga, LV-1067, LATVIA \\ ${ }^{3}$ Faculty of Education, Psychology and Art, University of Latvia, 1 Imantas $7^{\text {th }}$ Line, Rĩga, LATVIA \\ \# Corresponding author, oksana-kolesova@inbox.lv
}

Contributed by Ludmila Vikssna

\begin{abstract}
Cytokeratin 18 (CK18) is a specific marker of hepatocellular apoptosis, which is a useful noninvasive indicator of liver fibrosis in the HIV/HCV group. However, data on the CK18 level in serum are limited for this group. This study demonstrated CK18 levels in serum in HIV/HCV coinfected and HIV mono-infected patients; investigated the association of CK18 levels with other non-invasive markers of liver fibrosis; and presents CK18 dynamics in a four-month-long period. The sample included 273 patients with HIV infection (128 of them were with HIV/HCV coinfection) aged from 23 to 65 (35\% females). Levels of hyaluronic acid, CK18, ALT, and AST were determined in serum, and the FIB4 index was calculated. All markers had higher levels in the HIV/HCV group than in the HIV mono-infection group. The HIV/HCV group demonstrated coherent correlations among the markers and their associations with the level of CK18 than the HIV mono-infection group. During the four-month-long period, the CK18 level in serum showed no significant changes.
\end{abstract}

Key words: liver fibrosis, non-invasive test, hepatocyte apoptosis, CK18, HIV/HCV.

\section{INTRODUCTION}

Hepatitis $\mathrm{C}$ virus (HCV) is the second most common type of viral hepatitis that co-occurs with HIV infection. Of the 37 million people living with HIV worldwide, about 2.3 million are positive for antibodies to $\mathrm{HCV}$ (Platt et al., 2016). HCV co-infection can affect from 6\% (Platt et al., 2016) to $30 \%$ of HIV patients (Rockstroh et al., 2013), and up to $82 \%$ of people injecting drugs (Platt et al., 2016). $\mathrm{HCV}$ co-infection with HIV promotes faster progression of liver fibrosis than HCV mono-infection (Mohsen et al., 2003; de Lédinghen et al., 2008) or HIV infection without HCV (Kim et al., 2016). As a result, mortality rates in $\mathrm{HIV} / \mathrm{HCV}$ co-infected patients are higher than in patients with HIV infection without HCV (Rockstroh et al., 2013; Scherzer et al., 2017). Thus, it is important not only to detect liver fibrosis promptly but also to develop an optimal approach to reduce the progression of liver disease among HIV patients (Kim et al., 2016).
The pathogenesis of liver fibrosis is in detail described by a variety of authors (Canbay et al., 2004; Guicciardi and Gores, 2005; Friedman, 2010). Liver fibrosis occurs due to inflammation and hepatocyte apoptosis, which activate hepatic stellate cells (HSC) to produce collagen and other extracellular matrix molecules, as well as ferments, reducing the extracellular matrix degradation.

Hepatocyte apoptosis is an important pro-fibrogenic factor and, at the same time, the first response to different impacts, independently of their aethiology (Canbay et al., 2004; Guicciardi and Gores, 2005). Phagocytosis of apoptotic bodies by Kupffer cells and HSC increases their expression of pro-fibrogenic cytokine as transforming growth factor (TGF- $\beta$ ), other pro-inflammatory cytokines, and death ligands, which promotes HSC activation and enhances hepatocyte apoptosis. Non-phagocytosed apoptotic bodies release their content into the tissues and further enhance hepatocyte apoptosis and HSC activation. It should be noted that the re- 
lationship between apoptosis and fibrosis is bidirectional (Canbay et al, 2004). Evidence of this was demonstrated in a recent experimental study (Ganesan et al., 2018) and a clinical study (Vīksna et al., 2019).

Liver fibrosis in HIV/HCV co-infection associates with the cytopathic effect of HCV on hepatocytes and with the ability of HIV virus to induce direct and indirect liver injury (Chew and Bhattachatya, 2016). The most commonly described mechanisms of liver damage by HIV are the following. HIV envelop protein gp120 interacts with CCR5 and CXCR4 receptors - the main HIV co-receptors (Wilen et al., 2012) — on hepatocyte and HSC and directly cause hepatocyte apoptosis (Blackard and Sherman, 2008) and HSC activation (Hong et al., 2012). Moreover, HCV proteins activate HSC and increase the expression of both CXCR4 and CCR5 receptors on HSC (Hong et al., 2009). An important effect on liver damage during HIV infection is related to microbial translocation, which extremely increases after the substantial loss of $\mathrm{CD}^{+} \mathrm{T}$ cells residing in the gut (Marchetti et al., 2013). An increase of circulating lipopolysaccharides triggers Kupffer cells and induces their activation and production of TGF- $\beta$ and other pro- fibrogenic cytokines. During HIV infection, fibrogenesis in the liver is enhanced by dysregulation of the immune system, leading to an imbalance between the production of anti-fibrogenic and pro-fibrogenic cytokines, as well as by oxidative stress and mitochondrial damage (Kaspar and Sterling, 2017). Prolonged antiretroviral treatment (ART) can also enhance mitochondrial toxicity and hepatocyte apoptosis. Different drugs of the classes nucleoside / nucleotide reverse transcriptase inhibitors (NRTI) (Maagaard et al., 2009), protease inhibitors (PI) and non-nucleoside reverse transcriptase inhibitors (NNRTI) (Apostolova et al., 2011; Selvaraj et al., 2014) can affect liver injury.

Liver biopsy is traditionally used for the detection and assessment of liver fibrosis. At the same time, several studies in patients with $\mathrm{HIV} / \mathrm{HCV}$ indicate that serum hyaluronic acid (HA), tissue inhibitors of metalloproteinase (Laurrouse et al., 2007), AST-to-Platelets Ratio Index (APRI) (Schmid et al., 2015; Klieman et al., 2016), FIB4 index, and other non-invasive parameters and indexes (Schmid et al., 2015) have a significant correlation with the stage of liver fibrosis. Additionally, APRI, FIB4 index, and HA are highly predictive of liver disease outcome in HIV/HCV co-infected individuals (Nunes et al., 2010). Based on these studies, the use of these non-invasive tests for screening liver fibrosis is recommended in these patients, if transient fibroelastography is not available or impossible to perform (Schmid et al., 2015). However, there is no consensus on the specificity and sensitivity of parameters or indices and their "cut-off" levels for HIV/HCV patients (Sterling et al., 2006; Laurrouse et al., 2007; Rohrbach et al., 2013; Schmid et al., 2015; Klieman et al., 2016).

Cytokeratin 18 (CK18) is a specific indicator of hepatocyte apoptosis as it is mostly expressed by hepatocytes (Chu and Weiss, 2002). CK18 is elevated in patients with various liver diseases: acute and chronic viral hepatitis (Vīksna et al., 2009; Parfieniuk-Kowerda et al., 2014), patients with acute alcoholic hepatitis (Vīksna et al., 2009) and nonalcoholic steatohepatitis (Feldstein et al., 2009; Aida et al., 2014; Kobayashi et al., 2017). An increased CK18 level in blood was observed in patients with HIV mono-infection because of development of nonalcoholic steatohepatitis caused by longtime ART, dyslipidemia, and insulin resistance (Benmassaoud et al., 2018). Benmassaoud et al. (2018) noted that data about CK18 levels are not available for HIV mono-infected patients from Western countries.

There are limited studies about the CK18 level in serum in HIV patients co-infected with HCV. Using the keywords "Cytokeratin 18" AND "HIV" AND "HCV", only one publication was found in the PUBMED database regarding the level of CK18 in blood (Rohrbach et al., 2013). Rohrbach et al. (2013) demonstrated a positive association between CK18 and AST level and between CK18 level and the stage of liver fibrosis in METAVIR classification. At the same time, there was no association between CK18 and other markers of liver fibrosis in this group. Higher levels of CK18 in HIV/HCV patients than in HIV mono-infected patients have been shown previously in two studies in Latvian cohorts (Vīksna et al., 2019; Madelāne et al., 2019). Our study merges data from both Latvian studies and provides CK18 levels in a relatively large group of HIV/HCV coinfected and HIV mono-infected patients, and the association of CK18 levels with other non-invasive markers of liver fibrosis, and describes CK18 dynamics in a fourmonth-long period.

\section{MATERIALS AND METHODS}

This study combined two retrospective studies conducted in the frame of the National Research Programme "Biomedicine", Sub-project 5.7.1, "Host organism's determinants, predisposition and susceptibility to infections caused by RNA viruses (HIV, HCV, Tick-borne encephalitis), assessment of modulations of these determinants during the course of disease". Both studies were approved by the Ethics Committee of Rīga Stradiňš University (Nr. 42/ 30.04.2015), Ethics Committee of Rīga East University Hospital (Nr. 18-A/15, 06.08.2015), and by the Rìga East University Hospital Support Foundation of Medical and Biomedical Studies Ethics Committee on 5 May 2016, with corresponding ethical approval code No. 6-A/16. The inclusion criteria were: age $\geq 18$, confirmed HIV mono-infection, confirmed HIV and HCV co-infection, and available serum for additional testing. The exclusion criteria were: opportunistic infection, viral hepatitis B, alcoholic liver diseases, and liver cirrhosis or neoplasia.

The study sample included 273 patients aged from 23 to 65 (mean age was $39 \pm 9$ years, $35 \%$ females, $100 \%$ Caucasian). The median $\mathrm{CD} 4^{+}$cell count was 335 cells $/ \mu 1$, and the interquartile range (IQR) was $192-483$ cells $/ \mu 1$. The HIV/HCV group included 128 patients, of whom 73 received ART. The HIV mono-infection group included 145 patients (85 of them with ART). Two nucleoside reverse 
transcriptase inhibitors (NRTI) combined with one protease inhibitors (PI) or with one non-nucleoside reverse transcriptase inhibitor (NNRTI) were used for treatment.

The HIV diagnosis was based on positive HIV1/2 antibodies in serum, confirmed by Western Blott, and on detection of HIV RNA by real-time polymerase chain reaction (COBAS AmpliPrep/COBAS TaqMan HIV-1 Test 2.0, Roche, USA, the lower limit of detection was 20 copies/ $\mathrm{ml}$ ). The HCV co-infection was confirmed by a positive $\mathrm{HCV}$ antibody test (ELISA, Bio-Rad, France or Ortho-Clinical Diagnostics Inc., USA) and by detection of HCV RNA (COBAS AmpliPrep/COBAS TaqMan HCV test, Roche, USA) or HCV Core Ag (ELISA Architec system HCV Ag, Abbot, USA) in plasma.

In patient's serum the following parameters were detected: hyaluronic acid (HA) by Hyaluronic Acid test Kit (Corgenix, USA), cytokeratin 18 neoepitope by M30 Apoptosense ELISA kit Peviva (VLV bio, Sweden) according to manufacturer's recommendations, and alanine aminotransferase (ALT), aspartate aminotransferase (AST), and platelet count by using validated methods. The FIB4 index was calculated as FIB4 $=($ age $\times$ AST $) /$ (platelets $\left.\left(10^{9} / \mathrm{L}\right) \times \mathrm{ALT}^{1 / 2}\right)\left(\right.$ Sterling et al., 2006). The CD4 ${ }^{+} \mathrm{T}$ lymphocyte count was determined by flow cytometry.

Statistical analysis was performed with IBM SPSS for Windows 22.0 and the R-package 'nparLD'2.1 (Noguchi et al., 2012) as an implementation of the nonparametric approach to the analysis of longitudinal data in factorial settings.

\section{RESULTS}

Shapiro-Wilk test values varied from 0.57 to 0.94 , which indicated the non-normal distribution of markers under investigation. Therefore, the comparison of HIV and HIV/HCV was based on the Mann-Whitney $U$ test. The results revealed significantly higher levels of all markers of liver fibrosis in the HIV/HCV co-infection group (Table 1).

In $21.5 \%$ patients with HIV mono-infection and $39.6 \%$ patients with HIV/HCV co-infection, the level of FIB4 was greater than 1.45 - the level of absence of advanced fibrosis, following Sterling et al. (2006). It also confirmed an association of liver fibrosis with $\mathrm{HCV}, \chi^{2}(1)=8.70, p=$ 0.003 .

The relationships among markers of liver fibrosis were assessed in HIV mono-infection group and HIV/HCV co-infection group separately, taking into account differences between the two groups. Table 2 presents correlation coefficients in the HIV mono-infection group.

The level of CK18 was correlated positively with the level of ALT. FIB4 index was correlated positively with the level of HA and AST, while AST and ALT demonstrated a strong positive association.

In the group with $\mathrm{HIV} / \mathrm{HCV}$ co-infection, markers of liver fibrosis demonstrated stronger positive associations, and all of them were statistically significant (Table 3).
Table 1. Mann-Witney $\mathrm{U}$ test on markers of liver fibrosis and $\mathrm{CD}^{+}{ }^{+} \mathrm{T}$ lympocytes in HIV mono-infection and HIV/HCV co-infection groups

\begin{tabular}{l|c|c|c}
\hline \multicolumn{1}{c|}{ Markers } & $\begin{array}{c}\text { HIV Group } \\
(\mathrm{n}=145) \\
\text { Median (IQR) }\end{array}$ & $\begin{array}{c}\text { HIV/HCV Group } \\
(\mathrm{n}=128) \\
\text { Median (IQR) }\end{array}$ & $\mathrm{U}$ \\
\hline CK18, U/1 & $156(130-188)$ & $199(149-269)$ & $6198.5^{* * *}$ \\
FIB4 Index & $0.94(0.69-1.34)$ & $1.05(0.78-2.10)$ & $5071.0^{*}$ \\
HA, ng/ml & $18.9(14.4-27.6)$ & $27.0(17.0-45.9)$ & $5794.0^{* * *}$ \\
ALT, U/1 & $23(16-36)$ & $52(31-91)$ & $3352.5^{* * *}$ \\
AST, U/1 $^{*}$ CD4 ${ }^{+}$, cells $/ \mu 1$ & $22(18-30)$ & $44(26-78)$ & $3252.0^{* * *}$ \\
\hline
\end{tabular}

$\mathrm{HCV}$, viral hepatitis C; IQR, interquartile range; CK18, cytokeratin 18; HA, hyaluronic acid; ALA, alanine aminotransferase; AST, aspartate aminotransferase.

$* p<0.05 ; * * * p<0.001$

Table 2. Spearman's rank correlations among markers of liver fibrosis in the HIV mono-infection group $(\mathrm{n}=145)$

\begin{tabular}{l|c|c|c|c|c}
\hline \multicolumn{1}{c|}{ Markers } & CK18 & FIB4 & HA & ALT & AST \\
\hline CK18 & - & & & \\
FIB4 & 0.04 & - & & & \\
HA & 0.05 & $0.25 * *$ & - & & \\
ALT & $0.25 * *$ & 0.16 & 0.10 & - & \\
AST & 0.17 & $0.47 * * *$ & 0.07 & $0.79 * * *$ & - \\
\hline
\end{tabular}

CK18, cytokeratin 18; HA, hyaluronic acid; ALA, alanine aminotransferase; AST, aspartate aminotransferase.

$* * p<0.01 ; * * * p<0.001$

Table 3. Spearman's rank correlations among markers of liver fibrosis in the HIV/HCV co-infection group $(n=128)$

\begin{tabular}{l|c|c|c|c|c}
\hline \multicolumn{1}{c|}{ Markers } & CK18 & FIB4 & HA & ALT & AST \\
\hline CK18 & - & & & \\
FIB4 & $0.20^{*}$ & - & & & \\
HA & $0.19 *$ & $0.46 * * *$ & - & & \\
ALT & $0.32 * *$ & $0.41 * * *$ & $0.19 *$ & - & \\
AST & $0.28 * *$ & $0.64 * * *$ & $0.24 *$ & $0.84 * * *$ & -
\end{tabular}

CK18, cytokeratin 18; HA, hyaluronic acid; ALA, alanine aminotransferase; AST, aspartate aminotransferase.

$* p<0.05 ; * * p<0.01 ; * * * p<0.001$

The final step of analysis involved the assessment of the dynamics of the level of CK18 within four months. The comparison was performed in a subgroup of 36 patients, which were available for comparison (Table 4). The non-parametric, robust rank-based method for the analysis of longitudinal data (baseline vs four months) in two sub-groups (HIV mono-infection vs HIV/HCV co-infection) was applied following procedures suggested by Noguchi et al. (2012).

The results demonstrated no significant time effect and no interaction between $\mathrm{HCV}$ co-infection and time. The significant main effect was observed only for $\mathrm{HCV}$ co- 
Table 4. CK18 dynamics in four-months-long follow-up $(\mathrm{n}=36)$

\begin{tabular}{l|c|c}
\hline \multicolumn{1}{c|}{ Group } & $\begin{array}{c}\text { CK18 baseline } \\
\text { median (IQR) }\end{array}$ & $\begin{array}{c}\text { CK18 after 4 months } \\
\text { median (IQR) }\end{array}$ \\
\hline HIV $(\mathrm{n}=22)$ & $141.3(99.7-183.3)$ & $116.5(104.4-176.9)$ \\
HIV/HCV $(\mathrm{n}=14)$ & $202.8(139.1-266.2)$ & $199.2(120.9-317.7)$ \\
\hline Factor & ANOVA-type statistic & $p$ \\
HCV & 7.39 & 0.007 \\
Time & 0.76 & 0.382 \\
HCV $\times$ Time & 0.06 & 0.797 \\
\hline
\end{tabular}

HCV, viral hepatitis C; IQR,i range; CK18, cytokeratin 18

infection. It confirmed the difference between HIV and $\mathrm{HIV} / \mathrm{HCV}$ groups, revealed at the first step of the analysis.

\section{DISCUSSION}

In general, all of the investigated liver damage parameters were higher in the HIV/HCV group than in patients with HIV mono-infection. Differences between HIV and $\mathrm{HIV} / \mathrm{HCV}$ co-infection groups and the proportion of patients with FIB4 higher than 1.45 confirmed association of liver fibrosis with HCV co-infection (Kim et al., 2016).

The median and the first quartile values of CK18 in both groups were higher than 122 U/1 as the "cut-off" value suggested for this marker of hepatic apoptosis (Rohrbach et al., 2013). This indicates that both groups faced significant hepatic apoptosis. Simultaneously, the higher CK18 level in patients with $\mathrm{HIV} / \mathrm{HCV}$ co-infection than in patients with HIV mono-infection confirmed pronounced hepatocyte apoptosis during HIV/HCV co-infection (Macías et al., 2005).

The HIV/HCV group demonstrated a more coherent pattern of correlations among HA, AST, ALT, and FIB4 index and their associations with the level of CK18. In the study of Rohrbach et al. (2013), CK18 was correlated with AST only. The difference in correlation patterns between the studies can be addressed to the greater amplitude of markers. For example, IQR for CK18 in HIV/HCV group in our study was from $149 \mathrm{U} / 1$ to $269 \mathrm{U} / 1$, while in Rohrbach et al. (2013) it was from $83 \mathrm{U} / 1$ to $123 \mathrm{U} / \mathrm{l}$ (in a pre-ART group).

Previously, correlations between CK18 and AST or ALT were described in HIV mono-infected patients because of the presence of steatohepatitis developed due to insulin resistance, longtime ART, and dyslipidemia during the course of HIV infection (Benmassaoud et al., 2018). The positive relationship between CK18 and ALT was described in patients with chronic HCV without HIV infection (ParfieniukKowerda et al., 2014). Both transaminases are ferments in hepatocytes, and the relationship between CK18 and transaminases confirms the damage of hepatocytes during HIV/HCV co-infection.

An increased HA level in serum is the marker of liver fibrosis (Neunman et al., 2016). Correlation between CK18 and
HA confirms the theoretical relationship between hepatocyte apoptosis and liver fibrosis, described by Canbay et al. (2004), Guicciardi and Gores (2005) and Friedman (2010). A clinical study (Vìksna et al., 2019) also indicated that $\mathrm{HIV} / \mathrm{HCV}$ co-infection impacts CK18 indirectly through the level of HA.

In our study, the investigation of CK18 level in serum during the four-month-long period revealed no significant changes. This is in line with Rohrbach et al. (2013), who found no significant changes in CK18 level within a year in HIV/HCV patients under successful ART and pre-ART. In our study, the higher level of CK18 in HIV/HCV patients than in HIV mono-infected patients remained during this period.

The retrospective nature of our study forms its significant limitation. A relatively small number of patients in a fourmonth-long longitudinal study limited the assessment of CK18 dynamics. A longer follow-up interval is requested for a more precise evaluation of the dynamics. The multifactor model of liver fibrosis and a complex assessment of its markers remain the question for further investigation.

In general, our study provides information for a comparison of observed levels of CK18 and other non-invasive markers of liver fibrosis in a European country. The revealed levels of markers of liver fibrosis and apoptosis provide a basis for discussion on the improvement of the assessment of risk for patients with HIV mono-infection and HIV/HCV coinfection. Significant correlations of CK18 with markers of liver fibrosis and hepatocyte damage confirmed the significance of CK18 level in serum for the assessment of liver damage and fibrosis in patients with HIV/HCV co-infection.

\section{REFERENCES}

Aida, Y., Abe, H., Tomita, Y., Nagano, T., Seki, N., Sugita, T., Itagaki, M., Ishiguro, H., Sutoh, S., Aizawa, Y. (2014). Serum cytokeratin 18 fragment level as a noninvasive biomarker for non-alcoholic fatty liver disease. Int. J. Clin. Exp. Med., 7 (11), 4191-4198.

Apostolova, N., Gomez-Sucerquia, L. J., Gortat, A., Blas-Garcia, A., Esplugues, J. V. (2011). Compromising mitochondrial function with the antiretroviral drug efavirenz induces cell survival-promoting autophagy. Hepatology, 54 (3), 1009-1019.

Benmassaoud, A., Ghali, P., Cox, J., Wong, P., Szabo, J., Deschenes, M., Osikowicz, M., Lebouche, B., Klein, M. B., Sebastiani, G. (2018). Screening for nonalcoholic steatohepatitis by using cytokeratin 18 and transient elastography in HIV mono-infection. PloS ONE, 13 (1), e0191985.

Blackard, J. T., Sherman, K. E. (2008). HCV/HIV co-infection: Time to re-evaluate the role of HIV in the liver? J. Viral Hepat., 15, 323-330.

Canbay, A., Friedman, S., Gores, G. J. (2004). Apoptosis: The nexus of liver injury and fibrosis. Hepatology, 39 (2), 273-278.

Chew, K. W., Bhattacharya, D. (2016). Virologic and immunologic aspects of HIV-HCV co-infection. AIDS, 30 (16), 2395-2404.

Feldstein, A. E., Wieckowska,A., Lopez, A. R., Liu, Y.-C., Zein, N. N., McCullough, A. J. (2009). Cytokeratin-18 fragment levels as noninvasive biomarkers for nonalcoholic steatohepatitis: A multicenter validation study. Hepathology, 50, 1072-1078. 
Friedman, S. L. (2010). Evolving challenges in hepatic fibrosis. Nat. Rev. Gastroenterol. Hepatol., 7, 425-436.

Ganesan, M., Dagur, R. S., Makarov, E., Poluektova, L. I., Kadambi, S., Osna, N. A. (2018). Matrix stiffness regulate apoptotic cell death in HIV-HCV co-infected hepatocytes: Importance for liver fibrosis progression. Biochem. Biophys. Res. Commun., 500, 717-722.

Guicciardi, M. E., Gores, G. J. (2005). Apoptosis: A mechanism of acute and chronic liver injury. Gut, 54, 1024-1033.

Hong, F., Tuyama, A., Lee, T. F., Loke, J., Agarwal, R., Cheng, X., Garg, A., Fiel, M. I., Schwartz, M., Walewski, J., Branch, A., Schecter, A. D., Bansa, M. B. (2009). Hepatic stellate cells express functional CXCR4: Role in stromal cell-derived factor-1alphamediated stellate cell activation. Hepatology, 49, 2055-2067.

Hong, F., Saiman, Y., Si, C., Mosoian, A., Bansal, M. B. (2012). X4 Human iImmunodeficiency virus Type 1 gp120 promotes human hepatic stellate cell activation and collagen I expression through interactions with CXCR4. PLoS One, 7, e33659.

Kaspar, M. B., Sterling, R. K. (2017). Mechanisms of liver disease in patients infected with HIV. BMJ Open Gastro., 4, e000166.

Kim, H. N., Nance, R., Rompaey, S. V., Delaney, J. C., Crane, H. M., Cachay, E. R., Geng, E., Boswell, S. L., Rodriguez, B., Eron, J., Saag, M., Moore, R. D., Kitahata, M. M. (2016). Poorly controlled HIV infection: An independent risk factor for liver fibrosis. J. Acquir. Immune Defic. Syndr., 72 (4), 437-443.

Kliemann, D. A., Wolff, F. H., Tovo, C. V., Alencastro, P. R., Ikeda, M. L. R., Brandćo, A. B. M., Barcellos, N., Fuchs, S. C. (2016). Biochemical non-invasive assessment of liver fibrosis cannot replace biopsy in HIV-HCV coinfected patients. Ann. Hepatol., 15 (1), 27-32.

Chu, P. G., Weiss, L. M. (2002). Keratin expression in human tissues and neoplasms. Histopathology, 40, 403-439.

Kobayashi, N., Kumada, T., Toyoda, H., Tada, T., Ito, T., Kage, M., Okanoue, T., Kudo, M. (2017). Ability of cytokeratin-18 fragments and FIB4 index to diagnose overall and mild fibrosis nonalcoholic steatohepatitis in Japanese nonalcoholic fatty liver disease patients. Digestive Dis., 35 (6), 521-530.

Larrousse, M., Laguno, M., Segarra, M., De Lazzari, E., Martknez, E., Luis Blanco, J. L., León, A., Deulofeu, R., Miquel, R., Milinkovic, A., Lonca, M., Miró, J. M., Biglia, A., Murillas, J., Gatell, J. M., Mallolas, J. (2007). Noninvasive diagnosis of hepatic fibrosis in HIV/HCV-coinfected patients. J. Acquir. Immune Defic. Syndr., 46, 304-311.

de Lédinghen ,V., Barreiro, P., Foucher, J., Labarga, P., Castéra, L., Vispo, M. E., Bernard, P.-H., Martin-Carbonero, L., Neau, D., García-Gascó, P., Merrouche, W., Soriano, V. (2008). Liver fibrosis on account of chronic hepatitis $\mathrm{C}$ is more severe in HIV-positive than HIV-negative patients despite antiretroviral therapy. J. Viral Hepat., 15, 427-433.

Maagaard, A., Kvale, D., Scand, J. (2009). Long term adverse effects related to nucleoside reverse transcriptase inhibitors: Clinical impact of mitochondrial toxicity. Infect Dis, 41 (11-12), 808-817.

Macías, J., Japón, M. A., Sáez, C., Palacios, R. B., Mira, J. A., García-García, J. A., Merchante, N., Vergara, S., Lozano, F., Gómez-Mateos, J., Pineda, J. A. (2005). Increased hepatocyte Fas expression and apoptosis in HIV and hepatitis C virus co-infection. J. Inf. Dis., 192, 1566-1576.

Madelāne, M., Krūmiņa, A., Sīmanis, R., Šķenders, Ģ., Ivanovs, A., Stūre, G., Vìksna, L. (2019). Difference in markers of microbial translocation and cell apoptosis in HIV monoinfected and HIV/HCV coinfected patients. Proc. Latvian Acad. Sci., Section B, 73 (4), 304-311.

Marchetti, G., Tincati, C., Silvestri, G. (2013). Microbial translocation in the pathogenesis of HIV infection and AIDS. Clin. Microbiol. Rev., 26, 2-18.

Mohsen, A. H., Easterbrook, P. J., Taylor, C., Portmann, B., Kulasegaram, R., Murad, S., Wiselka, M., Norris, S. (2003). Impact of human immunode- ficiency virus (HIV) infection on the progression of liver fibrosis in hepatitis C virus infected patients. Gut, 52, 1035-1040.

Neuman, M. G., Cohen, L. B., Nanaua R. M. (2016). Hyaluronic acid as a non-invasive biomarker of liver fibrosis. Clin. Biochem., 49, 302-315.

Noguchi, K., Gel, Y. R., Brunner, E., Konietschke, F. (2012). nparLD: An R software package for the nonparametric analysis of longitudinal data in factorial experiments. J. Statist. Software, 50 (12), 1-23.

Nunes, D., Fleming, C., Offner, G., Craven, D., Fix, O., Heeren, T., Koziel, M. J., Graham, C., Tumilty, S., Skolnik, P., Stuver, S., Horsburgh Jr, C. R., Cotton, D. (2010). Noninvasive markers of liver fibrosis are highly predictive of liver-related death in a cohort of HCV-infected individuals with and without HIV infection. Amer. J. Gastroenterol., 105, 1346-1353.

Parfieniuk-Kowerda, A., Lapinski, T. W., Rogalska-Plonska, M., Swiderska, M., Panasiuk, A., Jaroszewicz, J., Flisiak, R. (2014). Serum cytochrome c and m30-neoepitope of cytokeratin-18 in chronic hepatitis C. Liver Int, 34, $544-550$.

Platt, L., Easterbrook, P., Gower, E., McDonald, B., Sabin, K., McGowan, C., Yanny, Razavi, H., Vickerman, P. (2016). Prevalence and burden of HCV co-infection in people living with HIV: A global systematic review and meta-analysis. Lancet Infect. Dis., 16, 797-808.

Rockstroh, J. K., Peters, L., Grint, D., Soriano, V., Reiss, P., Monforte, Ad., Beniowski, M., Losso, M. H., Kirk, O., Kupfer, B., Mocroft, A., for EuroSIDA in EuroCoord. (2013). Does hepatitis C viremia or genotype predict the risk of mortality in individuals co-infected with HIV? $J$. Hepatol., 59 (2), 213-220.

Rohrbach, J., Stickel, F., Schmid, P., Thormann, W., Kovali, H., Scherrer, A., Günthard, H. F., Vuichard, D., Cavassini, M., Ambrosioni, J., Bernasconi, E., Furrer, H., Rauch, A. and the Swiss HIV Cohort Study. (2013). Changes of biomarkers of liver disease during successful combination antiretroviral theraly in HIV/HCV-coinfected individuals. Antiviral Ther., 19, 149-159.

Scherzer, R., Heymsfield, S. B., Rimlanda, D., Rimlanda, D., Powdwrly, W. G., Tien, P. C., Bacchetti, P., Shlipak, M. G., Grunfeld, C. (2017). Association of serum albumin and AST with 5-year all-cause mortality in HIV/HCV coinfection and HIV monoinfection. AIDS, 31 (1), 71-79.

Schmid, P., Bregenzer, A., Huber, M., Rauch, A., Jochum, W., Müllhaupt, B., Vernazza, P., Opravil, M., Weber, R., Swiss HIV Cohort Study. (2015). Progression of liver fibrosis in HIV/HCV co-infection: A comparison between non-invasive assessment methods and liver biopsy. PLOS ONE, 10 (9), e0138838.

Selvaraj, S., Ghebremichael, M., Li, M., Foli, Y., Langs-Barlow, A., Ogbuagu, A., Barakat, L., Tubridy, E., Edifor, R., Lam, W., Cheng, Y.-C., Paintsil, E. (2014). Antiretroviral therapy-induced mitochondrial toxicity: Potential mechanisms beyond polymerase-ć inhibition. Clin. Pharmacol. Ther., 96 (1), 110-120.

Sterling, R. K., Lissen, E., Clumeck, N., Sola, R., Cassia, M., Correa, M. C., Montaner, J., Sulkowski, M. S., Torriani, F. J., Dieterich, D. T., Thomas, D. L., Messinger, D., Nelson, M. for the APRICOT Clinical Investigators. (2006). Development of a simple noninvasive index to predict significant fibrosis in patients with HIV/HCV co-infection. Hepatol. Baltim. Md, 43, 1317-1325.

Vīksna, L., Keišs, J., Sočṇevs, A., Rozentāle, B., Pilmane, M., Sevastjanova N., Buik̦e, I., Jēruma, A., Eglìte, J., Ābeltiṇa K., Sondore, V. (2009). Novel laboratory tests in assessment of liver function and acute and chronic viral liver diseases. Proc. Latvian Acad. Sci., Section B, 63 (4/5), 228-233.

Vīksna, L., Ekšteina, I., Madelāne, M., Zeltinna, I., Krūmiṇa, A., Koḷesovs, A., Simanis, R. (2019). Markers of liver fibrosis and apoptosis in patients with HIV mono-infection and HIV/HCV co-infection. HIV AIDS Rev., 18 (1), 33-39.

Wilen, C. B., Tilton, J. C., Doms, R. W. (2012). HIV: Cell binding and entry. Cold Spring Harb. Perspect. Med., 2:a006866. 


\section{CITOKERATĪNA 18 LİMENIS PACIENTIEM AR HIV INFEKCIJU UN VĪRUSA HEPATĪTA C KOINFEKCIJU LATVIJĀ}

Citokeratīns 18 (CK18) ir hepatocelulāras apoptozes rādītājs, kas ir noderīgs aknu fibrozes novērtēšanā ar neinvazīvajiem markieriem HIV/HCV grupā. Tomēr dati par CK18 līmeni serumā šajā pacientu grupā ir ierobežoti. Šis pētījums parāda CK18 līmeni serumā pacientiem ar HIV/HCV koinfekciju un HIV monoinfekciju, atklāj CK18 saistību ar citiem neinvazīviem aknu fibrozes markieriem un novērtē CK18 dinamiku četru mēnešu ilgā periodā. Paraugkopā bija iekḷauti 273 pacienti ar HIV infekciju (128 no tiem bija ar HIV/HCV koinfekciju) vecumā no 23 līdz 65 gadiem (35\% bija sievietes). Serumā tika noteikta hialuronskābe, CK18, ALT un AST, un tika aprēķināts FIB4 indekss. Visi marķieri HIV/HCV grupā vairāk atšķ̄īās no normas nekā pacientiem ar HIV monoinfekciju. HIV/HCV grupā tika atklāts vairāk korelāciju starp izmeklētiem aknu fibrozes marķieriem un CK18 līmeni nekā grupā ar HIV monoinfekciju. Četru mēnešu ilgā periodā CK18 līmenis serumā neuzrādīja būtiskas izmaiṇas. 